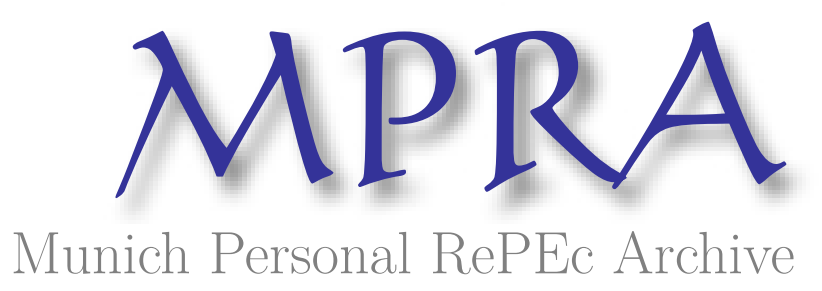

\title{
Abuse of collective dominance under the competition law of the Russian Federation
}

Avdasheva, Svetlana and Goreyko, Nadezhda and Pittman, Russell

Higher School of Economics, New Economic School, U.S. Department of Justice

22 September 2011

Online at https://mpra.ub.uni-muenchen.de/33742/

MPRA Paper No. 33742, posted 26 Sep 2011 23:45 UTC 
Abuse of Collective Dominance under the Competition Law of the Russian Federation ${ }^{1}$

By Svetlana Avdasheva ${ }^{*}$, Nadezhda Goreyko ${ }^{* *}$, and Russell Pittman ${ }^{* * *}$

Draft 9/22/11

\begin{abstract}
In 2006, Russia amended its competition law and added the concepts of "collective dominance" and its abuse. This was seen as an attempt to address the common problem of "conscious parallelism" among firms in concentrated industries. Critics feared that the enforcement of this provision would become tantamount to government regulation of prices. In this paper we examine the enforcement experience to date, looking especially closely at sanctions imposed on firms in the oil industry. Some difficulties and complications experienced in enforcement are analyzed, and some alternative strategies for addressing anticompetitive behavior in concentrated industries discussed.

\section{INTRODUCTION}

In 2006, Russia amended its competition law. Among many changes made, perhaps the most important was the introduction of the concept of "collective dominance", as a part of the associated and implicit concept of the abuse of collective dominance (Article 5). Along with the detailed elaboration of the concept of a "monopolistically high price" (Article 6) and the introduction of the concept of "concerted practices" (Article 8), the introduction of this new concept led businesses and analysts to fear that the new law would be used to control directly the prices charged by firms in concentrated markets.

\footnotetext{
${ }^{1}$ The authors are grateful for helpful comments by Andrei Shastitko.

${ }^{*}$ Professor of Economics, Higher School of Economics, Moscow.

** Junior Researcher, Institute for Industrial and Market Studies, Higher School of Economics, Moscow.

${ }^{* * *}$ Director of Economic Research, Antitrust Division, U.S. Department of Justice, and Visiting Professor, New Economic
} School, Moscow. The views expressed are not purported to reflect the views of the U.S. Department of Justice. 
Of course, this broad issue is not unique to Russia, nor new to the area of competition law and policy. In a concentrated market, a small number of firms may be able to easily observe each other's actions and thus to behave in a manner that is better characterized as cooperative than competitive. Furthermore, if the number of firms is sufficiently small and important market characteristics (like price) sufficiently transparent, the firms may behave in this cooperative manner without the necessity of resorting to explicit discussions or agreements. As we will discuss below, attempts by competition authorities in other jurisdictions - principally the US and the EU - to attack such cooperative behavior as illegal under the competition law have not met with much success. Tribunals and judges have been loath to punish firms for simply behaving in their own long-term interest, and have asked how they are to order the firms to pretend that they cannot observe the behavior of the other firms in the market and predict the reactions of rivals to their behavior. The introduction of the concept of the abuse of a position of collective dominance - a seemingly straightforward extension of the standard concept of the abuse of a position of individual firm dominance - was an attempt by the Federal Antimonopoly Service (FAS) of the Russian Federation to allow enforcers to attack tacit collusion directly, moving beyond existing limitations to attacking such behavior as a form of prohibited horizontal "agreement" - under Section 1 of the Sherman Act, for example, or under Article 101 of the Treaty of Lisbon. However, there are reasons why this avenue of competition law enforcement has run into difficulties in other jurisdictions, and some of these have come to the fore in the short enforcement experience of FAS with this provision of the law. ${ }^{2}$

In what follows, we will describe the background and context in which these changes in the Russian competition law took place, with an emphasis on the introduction of the concept of collective dominance (Section II of the paper); consider the use of the concepts of collective dominance, conscious

\footnotetext{
${ }^{2}$ A valuable recent discussion of these issues is provided in Andrey Shastitko, Collective Dominance Through the Lens of
} Comparative Antitrust, CPI Antitrust Chronicle, August 2011 (2). 
parallelism, and tacit collusion in other jurisdictions worldwide, particularly the European Union and the United States (Section III); relate in more detail the consequences of the new law as feared by businesses and analysts (Section IV); and describe the enforcement experience since the new law was enacted (Section V).

\section{APPEARANCE OF THE CONCEPT OF COLLECTIVE DOMINANCE IN RUSSIAN ANTIMONOPOLY LAW}

The doctrine of collective dominance did not appear in the Russian antitrust legislation by accident: its introduction was inspired by the contradiction between huge demand on competition policy measures and restricted abilities of anti-monopoly authorities. The Russian economy is dominated by resource-extracting, capital-intensive industries, each with a small number of interdependent producers. Structural characteristics of Russian markets make them prone to tacit collusion as a set of independent sellers' strategies. ${ }^{3}$ Traditions of tight horizontal coordination of prices under socialism strengthened the incentives for tacit as well as explicit collusion as a part of normal business practice. Only ten years ago about one third of general directors of Russian manufacturing enterprises were sure that producers colluding to fix prices are not subject to sanctions under the anti-monopoly law. ${ }^{4}$

Russian antitrust authorities historically have had limited capacity to prevent not only tacit coordination, but also explicit collusion. FAS and its regional branches have had no right to conduct clandestine investigations on their own. Lack of power complicated the gathering of direct evidence of price-fixing and market-sharing agreements. Only recently, cooperation between FAS and the Ministry

${ }^{3}$ M. Ivaldi, B. Jullien, P. Rey, P. Seabright, and J. Tirole, The Economics of Tacit Collusion, Report prepared for the European Commission, IDEI, Toulouse, 2003, http://ec.europa.eu/comm/competition/mergers/review/the economics of tacit collusion en.pdf.

${ }^{4}$ H. G. Broadman, Reducing Structural Dominance and Entry Barriers in Russian Industry, Review of Industrial Organization 17 (2000), 155-175, at 167. 
of Internal Affairs RF has permitted the gathering of evidence of overt anti-competitive agreements. The ability to detect and sanction tacit as opposed to overt collusion has been even more limited.

On the other hand, from the first years of competition law enforcement in Russia, the antitrust authorities have more effectively initiated and won cases of abuse of dominance (Article 5 of the original law [On competition and restriction of monopolistic activity, 1991] and Article 10 of the 2006 law [On protection of competition]). Evidence that supports the conclusion on dominance itself is based on structural analysis, which is significantly more developed in Russia than analysis of conduct. This facilitates the cases against dominant market participants. Guidelines for market competition analysis elaborated by FAS also concentrate mostly on the structural features of markets as indicators of competition. Many authors explain the introduction of the collective dominance doctrine in Russian anti-monopoly legislation as an attempt to reduce enforcement costs by addressing the market structure that is the ultimate cause of high prices rather than continually addressing the symptoms - the high prices themselves. ${ }^{5}$

In the new version of the law "On protection of competition" adopted in 2006, collective dominance is defined as a market in which all of the following conditions are present:

1) "The sum of the shares of the three (five) biggest economic entities on the market is no less that 50\% (70\%), while the shares of each are no less than $8 \%$;

2) During a long period... the relative sizes of economic entities' shares are stable or subjected to insignificant changes, as well as access of new competitors to the relevant market is impeded;

3) ... Information about the prices, conditions of selling or purchasing in the relevant market is available to indefinite group of persons [that is, is publicly available]...."

\footnotetext{
${ }^{5}$ S.N. Tchirihin, Gasoline market: it is possible to restrict monopolism? EKO Journal 6 (2006), 17-29 (С.Н. Чирихин, Рынок
} бензина: возможно ли ограничить монополизм? ЭКО 6 (2006), 17-29). 
As we will discuss below, the concept of a position of collective dominance in a market has been used by EU competition authorities for some years now. However, most proponents of the doctrine of collective dominance in the EU competition law probably did not anticipate the use of the concept provided by the Russian legislation. According to one of the most prominent European experts, Patrick Rey, in order to prevent collusion, the doctrine of collective dominance should be used primarily as a basis for the detection and prevention of "facilitating practices". ${ }^{6}$ Another direction where the notion of collective dominance could be applied in antitrust policy is in merger control. The idea of attacking similar, parallel actions of firms using primarily evidence on market structure is rejected: "In the absence of any hard evidence of explicit agreement ... it is difficult if not impossible to directly fight collusion per se". In particular, Rey and others ${ }^{7}$ have emphasized the risk of over-enforcement under a regime of attacking tacit collusion directly: the likelihood that in concentrated markets, a competition authority may become essentially a price and output regulator.

The issue of collective dominance becomes important not only in the framework of antitrust enforcement in Russian, but in the general context of economic policy in Russia after the prosecution of its four biggest oil companies (LUKoil, Rosneft, TNK-BP, Gazpromneft). In autumn 2008, these companies were accused of abuse of collective dominance in four markets: gasoline, diesel fuel, aviation kerosene, and furnace fuel oil. A final guilty verdict was issued by the RF Supreme Arbitration Court for TNK-BP in

\footnotetext{
${ }^{6}$ P. Rey, Collective dominance and the telecommunication industry, in P.A. Buiges and P. Rey, eds, The economics of
} antitrust and regulation in telecommunications: perspectives for the new European regulatory framework, Edward Elgar, 2004, pp. 91-113.

${ }^{7}$ For example, Jason Gudofsky, Evangelia Litsa Kriaris, and Lucian Vital, Abuse of Joint Dominance: Is the Cure Worse than the Disease? Canadian Bar Association, 2010, Annual Competition Law Conference. www.cba.org/cba/cle/PDF/COMP10 Gudofsky_paper.pdf. 
May 2010 and for Gazpromneft in February 2011. The original total of fines imposed on the companies was over 26 billion RF Rubles or about 1 billion USD. However in the autumn of 2010, an agreement between the RF government and some of the oil companies was achieved. This agreement resulted in a reduction of the amount of the fines but left unresolved the fundamental questions on the criteria of guilt in collective dominance cases. More information regarding lawsuits against Russian companies for abuse of collective dominance is presented in Section V.

\section{COLLECTIVE DOMINANCE, CONSCIOUS PARALLELISM, AND TACIT COLLUSION IN THE}

\section{COMPETITION LAWS OF OTHER COUNTRIES}

As suggested above, the jurisdiction whose competition law jurisprudence regarding tacit collusion among oligopolists is closest to that of the Russian Federation is probably the European Union. EU competition law recognizes the concept of "collective dominance" in the context of both abuse of a dominant position - Article 102 of the Treaty of Lisbon - and merger review - Merger Regulation $139 / 2004$, the "ECMR". Furthermore, although this was not clear for some time, it is now established that the concept of collective dominance is the same in both applications.

Early Commission decisions emphasized the importance of "economic links" among firms in the same market as a primary determinant of the presence of collective dominance (Flat Glass ${ }^{8}$ ), a concept later expanded upon to include the ability of the firms to present a "united front" to customers (CEWAL and $T A C A^{10}$ ) and "a relationship of interdependence existing between the parties to a tight oligopoly" $\left(\right.$ Gencor $\left.^{11}\right)$. More recently, a set of three criteria for the presence of collective dominance was set out $\left(\right.$ Airtours $\left.^{12}\right)$ :

\footnotetext{
${ }^{8}$ Cases T-68, 77, and 78/89, Societá Italiana Vetro SpA v. Commission [1992] ECR II-1403, [1992] 5 CMLR 302.

${ }^{9}$ [1993] OJ L34/20, [1995] 5 CMLR 198.

${ }^{10}$ Transatlantic Conference Agreement [1999] OJ L95/1, [1999] 4 CMLR 1415: on appeal, Case T-191/98. 30 Sept. 2003.

${ }^{11}$ Case T-102/96, Gencor Ltd v. Commission [1999] 4 CMLR 971.

${ }^{12}$ Case T-342/99, [2002] ECR II-2585, [2002] 5 CMLR 317.
} 
- First, market transactions must be sufficiently transparent that the oligopolists may monitor each others' behavior;

- Second, there must be means to retaliate if one oligopolist behaves too competitively; and

- Third, the coordinated outcome should be unlikely to be disturbed by actions of either competitors or customers. ${ }^{13}$

Regarding EU merger enforcement, the concept of collective dominance was much more important before the revisions to the ECMR in 2004, since the original regulation prohibited only those mergers that would "result in the creation or strengthening of a dominant position." Without the concept of collective dominance, that formulation would have dictated an enforcement focus aimed much more directly at "unilateral effects" than at "coordinated effects". Now that the regulation also prohibits mergers that would "significantly impede effective competition", concerns about mergers that may increase the likelihood of oligopolistic coordination may be addressed without so much focus on the concept of collective dominance.

However, for purposes of comparison with the Russian situation, it is the definition and interpretation of the abuse of collective dominance that is most relevant. Here the distinction between exploitative and exclusionary abuses becomes relevant as well. In principal it would seem possible for the EC to bring enforcement actions against high prices charged by oligopolists, as the FAS has done, under the rubric of the exploitative abuse of a position of collective dominance. However, the Commission has rarely brought cases against firm pricing behavior under Article 102. Thus, as Jones and Sufrin argue,

${ }^{13}$ Alison Jones and Brenda Sufrin, EC Competition Law: Text Cases, and Materials ( $3^{\text {rd }}$ ed.), Oxford University Press, 2007; Olivier Billard, Marc Ivaldi, and Sébastien Mitraille, Evaluation of the Risks of Collective Dominance in the Audit Industry in France, working paper, Toulouse School of Economics, Mai 2011. 
Although it would ... seem possible, in principle, for the Commission to condemn oligopolists that have engaged in parallel pricing at a level that the Commission considers to be "excessive" [as an abuse of collective dominance,] it seems extremely unlikely that it would attempt to do so.

Where the Commission has taken some action against collective dominance under Article 102 is in the realm of exclusionary abuses. In CEWAL and TACA, the Commission found that members of a liner conference in ocean shipping had abused their position of collective dominance by taking parallel actions that discouraged entry into the market. Interestingly, in Irish Sugar ${ }^{14}$ the Commission, upheld by the Court of First Instance, found that an individual firm could be found guilty of abusing the position of collective dominance that it occupied with its competitor oligopolists.

Overall, however, it appears that the difficulty of applying the concept of abuse of dominance to the parallel behavior of oligopolists will limit the use of this enforcement tool by the Commission in the future. Indeed, as noted by other analysts, the Commission's most recent guidance on its enforcement of Article 102 mentions the concept of collective dominance only in its caveat that the document does not address the issue at all. ${ }^{15}$

In the United States, the concept of collective dominance has for the most part been considered under the rubric of "conscious parallelism", and examined in the context of illegal agreements under Section 1 of the Sherman Act, rather than in the context of monopolization under Section 2.

Cases from a number of years ago made clear that agency enforcement actions seeking to sanction coordinated behavior among oligopolists would face clear limits. The attempt by the Federal Trade

\footnotetext{
${ }^{14}$ Irish Sugar plc v. Commission [1997] OJ L258/1, [1997] 5 CMLR 666.

${ }^{15}$ Sophia Stephananou, Collective Dominance Through Tacit Coordination: The Case for Non-Coordination Between
} Article 82 and Merger Control "Collective Dominance" Concepts, GCP: The Antitrust Chronicle, October 2009 (1), and Lia Vitzilaiou and Constantinos Lambadarios, The Slippery Slope of Addressing Collective Dominance Under Article 82 EC, GCP: The Antitrust Chronicle, October 2009, discussing http://eurlex.europa.eu/LexUriServ/LexUriServ.do?uri=CELEX:52009XC0224(01):EN:NOT. 
Commission in 1982 to address collective dominance as "shared monopoly" behavior in the breakfast cereal industry, to be considered illegal as an "unfair practice" under Section 5 of the FTC Act, was not successful. ${ }^{16}$ The Federal Trade Commission was also unsuccessful in its Ethyl ${ }^{17}$ and DuPont ${ }^{18}$ cases (1983-84) attacking the parallel adoption by oligopolists of "facilitating practices" - conventions such as quoting delivered prices only and announcing price changes in advance, arguably in order to "facilitate" tacit collusion - as illegal agreements under Section $1 .{ }^{19}$

In the context of Section 1, the courts have made it clear that parallel behavior, by itself, does not prove a conspiracy and is therefore not illegal (Theatre Enterprises ${ }^{20}$ ). Rather, for parallel behavior to constitute evidence of a conspiracy, it must be accompanied by certain "plus factors", such as evidence of "raising prices in time of oversupply" (American Tobacco ${ }^{21}$ ), "artificial standardization of products", and "pretextual explanations for a course of action". As summarized by a leading treatise,

Among the most important plus factors are those that tend to show that the conduct would be in the parties' self-interests if they all agreed to act in the same way but would be contrary to their selfinterests if they acted alone. ${ }^{22}$

\footnotetext{
${ }^{16}$ See, e.g., Richard Schmalensee, Entry Deterrence in the Ready-To-Eat Breakfast Cereals Industry, Bell Journal of
} Economics 9 (1978), 305-27; Brian Harris, Shared Monopoly and the Cereal Industry, Graduate School of Business Administration, Michigan State University, 1979; F.M. Scherer and David Ross, Industrial Market Structure and Economic Performance ( $3^{\text {rd }}$ ed.), Houghton Mifflin, 1990; and David Kaserman and John Mayo, Government and Business: The Economics of Antitrust and Regulation, Dryden Press, 1995.

${ }^{17}$ In the matter of Ethyl Corp. et al., 101 F.T.C. 425 (1983).

${ }^{18}$ E.I. du Pont de Nemours Co. et al. v. Federal Trade Commission, 729 F. 2d 128 (1984).

${ }^{19}$ Scherer and Ross, ibid.; Kaserman and Mayo, ibid.

${ }^{20}$ Theatre Enterprises, Inc. v. Paramount Film Distributing Corp. et al., 346 U.S. 537 (1954).

${ }^{21}$ American Tobacco Co. et al. v. U.S., 328 U.S. 781 (1946).

${ }^{22}$ American Bar Association, Section of Antitrust Law, Antitrust Law Developments (6 $6^{\text {th }}$ ed.), 2007. 
And of course US competition law has no provision regarding the "monopolistically high price of goods" (as defined in Article 6 of the Russian law), concerning either individual firms or groups of firms.

Other jurisdictions around the world have amassed little experience so far with the concept of the abuse of a position of collective dominance. Recent guidelines issued by the Canadian authority may signal an intention to attack parallel behavior in concentrated industries, but there is no jurisprudence as yet. ${ }^{23}$ The Korean Fair Trade Commission brought a case against the abuse of collective dominance by twelve credit-card-issuing banks in 2005; the Supreme Court overturned the KFTC decision but expressed a willingness to accept the doctrine of collective dominance as a matter of law. ${ }^{24}$

\section{COLLECTIVE DOMINANCE IN ANTITRUST ENFORCEMENT IN RUSSIA: WHERE THE RISKS OF MISUSE COME FROM}

There are at least three important differences between Russian and European antitrust enforcement against abusive practices. First is a large number of cases in Russia on abuse of dominance (about 2 - 2.5 thousand cases annually, and this number continues to grow). Second is the focus of the abuse cases, significantly skewed towards the cases on exploitative behavior in contrast to exclusionary behavior. Third are the apparently low standards of proof of abuse when there is direct evidence of harm to a counterparty - that is, a customer, competitor, or supplier of the dominant firm. Let us consider two examples: excessive price ('high monopolistic price' as defined in the law), and unjustified difference of prices and other contractual terms (discrimination) by a dominant supplier.

Article 6 of the competition law contains two criteria by which prices may be judged to be excessive or monopolistically high: the excess of price over the price in a comparable competitive market and the

\footnotetext{
${ }^{23}$ Anita Banicevic and Mark Katz, Collective Dominance in Canada: A New Direction, GCP: The Antitrust Chronicle, November 2009; Gudofsky, Kriaris, and Vital, supra.

${ }^{24}$ Sai Ree Yun, Seuk Joon Lee, and Sangwook Daniel Han, Korea, in Thomas Janssens and Thomas Wessely, eds., Dominance: The regulation of dominant firm conduct in 40 jurisdictions worldwide, GCR: Getting the Deal Through, 2010.
} 
excess of price over the costs and profits necessary for production and sale of goods. However, the requirements for market comparability are so high that in most cases competition authorities and courts must utilize the second criterion and compare price with cost. In turn, FAS tends to estimate costs on the basis of accounting reports designed for tax collection purposes, with the result that important components of the economic costs, particularly for companies in capital-intensive industries, may be underestimated. The issue of "necessary and reasonable" cost and profit remains the most difficult and contentious in Russian cases on "excessive price". There are no legal standards for price-cost margin or rate of return on capital invested. The typical analysis used by FAS involves the comparison of changes in price with changes in cost: it is presumed that if the increase in prices substantially exceeds the increase in costs, this is evidence of abuse. This approach induces market participants to seek standards of "fair" or "allowable" price-cost margins in negotiations with antitrust authorities and government. For instance, the CEOs of at least two of the four Russian oil companies accused of charging excessive prices expressed willingness to follow prices set by government from the very start of litigation. In this way use of collective dominance doctrine in Russia becomes a method of "quasi-price regulation".

Issues of the precise nature of a violation and standard of proof arise also in cases alleging that a firm has engaged in price discrimination (prohibited as an abuse of dominance in Article 10 of the law). In practice, even accidental, unsystematic differences in prices have sometimes been considered illegal by antitrust authorities and courts, and whether different transactions are in fact equivalent may be given little attention. According to the decisions of the Supreme Arbitration Court on the cases against TNK-BP (May 2010) and Gazpromneft (February 2011), sufficient requirements for equivalence are the physical equivalence of the product and the same legal form of the contract. The illegality of "unjustified price differences" seems to reflect a general trend of Russian antitrust policy to prohibit and punish the harm imposed on buyers from and/or sellers to the dominant firm or firms. Different contractual terms or different conditions of contract fulfillment by a dominant supplier seem to be attacked as illegal not so much because they may restrict competition as because they harm the counterparty. 
In these circumstances, the opportunity to qualify the company as a participant in a collectively dominant group of sellers creates a high risk of antitrust litigation. More information on the standards of evidence in cases of abuse of a collectively held dominant position is presented in Section V.

Introduction of the doctrine of collective dominance in the Russian antitrust legislation and enforcement practice has evoked criticism from both lawyers and economists. The difference lies in the focus of the criticism. For economists the focus has been first on the standards of evidence and proof of abusive conduct, ${ }^{25}$ and second on the concept itself of seeking to render tacit collusion as illegal. In particular, Russian economists have argued that the low standards of proof for abusive actions only exacerbate the more general problem of a high risk of Type I errors (false positives) in the enforcement of antitrust prohibitions against tacit collusion.

Russian lawyers, on the other hand, have focused their criticism more on the standards for evidence necessary to qualify the companies as collectively dominant. ${ }^{26}$ First, the idea is put forward that qualifying a group of sellers as collectively dominant should require an analysis not only of market structure, but also of the actual cooperation between the companies. With reference to the Flat Glass case $^{27}$-- that is, to the early European approach to the definition of collective dominance -- Russian

\footnotetext{
${ }^{25}$ Svetlana Avdasheva, ed., Development and application of antitrust law in Russia: the path of progress and errors,
} Moscow, Higher School of Economics, 2011 (С. Авдашева, ред', Развитие и применение антимонопольного законодательства в России: по пути достижений и заблуждений, Доклад. М., НИУ ВШЭ, 2001. Интернет-адрес: http://www.hse.ru/data/2011/04/05/1211687919/A D K Yu.pdf); Andrey Shastitko, Economic and legal foundations of collective dominance, Ekonomicheskaya politika 3 (2010), 167-190 (А. Шаститко, Экономико-правовые аспекты коллективного доминирования, Экономическая политика 3 (2011), 167-190).

${ }^{26}$ O. Migitko, Collective dominance: lack of proof and clarity, Competition and Law Journal 1 (2010), 8-14 (О. Мигитко, Коллективное доминирование - недоказанность и недосказанность, Конкуренция и право 1 (2010), 8-14. Интернетадрес: http://www.cljournal.ru/nomer1/15/).

27 L. Papadias, Some thoughts on collective dominance from a lawyer's perspective, in Buiges and Rey, op. cit., 114-131. 
lawyers advocate the inclusion of evidence of structural links and/or joint projects as a necessary indicator of collective dominance. A second proposal would complete the legal definition of collective dominance by requiring evidence of explicit communication and/or cooperation between sellers. A third would use as additional evidence of collective dominance a high share of the biggest seller in the market (over 35\%) under which the hypothesis on individual dominance cannot be rejected. Moving to the concept of the abuse of the position of collective dominance, a fourth proposal suggests that the abuse of dominant position should be able to be proven only for all members of collectively dominant group (instead of for individual firms, as has often been the case).

\section{APPLICATION OF THE LEGAL REGULATION OF COLLECTIVE DOMINANCE}

To analyze how the concept of collective dominance, as well as its abuse, has been applied, we sought to collect all decisions of FAS and the courts in which collective dominance was considered. We found 33 cases using publicly available sources. This data was collected from FAS and its regional subdivisions and from decisions of courts at different levels (Arbitration tribunals, Courts of appeal, Federal arbitration courts). There were several restrictions on our ability to collect data. First, the text of decisions on recognition of economic entities as collectively dominant are not always accessible on the websites of FAS and its regional subdivisions. This is particularly a problem for regional subdivisions of FAS. Second, FAS sometimes uses data that contain commercial secrets, so confidentiality rules mean that not all the text of some decisions is disclosed. Therefore there are often conclusions that state that economic entities are collective dominant in the market, but for the reader there is no way to discover what type of evidence confirms the conclusion.

Due to these restrictions on information about cases relating to collective dominance, we assume that if the text of a FAS or court decision mentions an indicator of collective dominance (the indications of collective dominance are in Art. 5, part 3, paragraphs 1-3 of the Law, as summarized earlier in this paper), then FAS based its analysis on this indicator and used it to prove or disprove 
collective dominance in the market. We will consider first the entire set of cases and then proceed to analyze more closely the important and controversial cases against the oil companies.

\section{A. CASES CONCERNED WITH COLLECTIVE DOMINANCE: A BROAD VIEW}

The collected cases cover a period of four years: the first decision we have found was approved on April 2007, and the last one was approved on April 2011. Violations of the Law were found by FAS in many different product markets overall, but nearly half of the total were in gasoline and diesel fuel markets. Geographical market boundaries also differ across cases. In our sample we have cases where market boundaries are the city, the region, and the whole country. (There are no cases in our sample where the geographic market found is larger than the territory of the Russian Federation.) The information on all the decisions of FAS that we found is presented in Table 1. 
Table 1. Decisions of FAS and its Regional Subdivisions Made on the Basis of Legal Regulation of Collective Dominance

\begin{tabular}{|c|c|c|c|}
\hline $\begin{array}{c}\text { Data, number of decision/order, } \\
\text { authority }\end{array}$ & Product market & $\begin{array}{l}\text { Geographical } \\
\text { market }\end{array}$ & $\begin{array}{l}\text { Violation (№ } \\
\text { Art.)** }\end{array}$ \\
\hline $\begin{array}{l}\text { 04.04.2011 № } 126 \text { FAS of } \\
\text { Kurganskaya oblast }\end{array}$ & wholesale of flour & local market & 10 \\
\hline 08.07.2009 № 1 10/27-09 FAS & $\begin{array}{l}\text { wholesale market of gasoline, diesel fuel and } \\
\text { aircraft kerosene }\end{array}$ & territory of Russia & 10 \\
\hline 10.09.2009 № 1 10/26-09 FAS & $\begin{array}{l}\text { wholesale market of gasoline, diesel fuel and } \\
\text { aircraft kerosene }\end{array}$ & territory of Russia & 10 \\
\hline 29.07.2009 № 1 10/28-09 FAS & $\begin{array}{l}\text { wholesale market of gasoline, diesel fuel and } \\
\text { aircraft kerosene }\end{array}$ & territory of Russia & 10 \\
\hline 25.06.2009 № 1 10/25-09 FAS & wholesale market of gasoline and aircraft kerosene & territory of Russia & 10 \\
\hline 27.10.2008 №1 10/64-08 FAS & $\begin{array}{l}\text { wholesale market of gasoline, diesel fuel, heating } \\
\text { fuel oil and aircraft kerosene }\end{array}$ & territory of Russia & 10 \\
\hline 26.09.2008 №1 10/63-08 FAS & $\begin{array}{l}\text { wholesale market of gasoline, diesel fuel, heating } \\
\text { fuel oil and aircraft kerosene }\end{array}$ & territory of Russia & 10 \\
\hline
\end{tabular}




\begin{tabular}{|c|c|c|c|c|}
\hline & 28.10.2008 №1 10/62-08 FAS & $\begin{array}{l}\text { wholesale market of gasoline, diesel fuel, heating } \\
\text { fuel oil and aircraft kerosene }\end{array}$ & territory of Russia & 10 \\
\hline & 10.10.2008 №1 10/61-08 FAS & $\begin{array}{l}\text { wholesale market of gasoline, diesel fuel, heating } \\
\text { fuel oil and aircraft kerosene }\end{array}$ & territory of Russia & 10 \\
\hline 0 & $\begin{array}{l}\text { 12.10.2010 № 02-01-42-10-10 FAS of } \\
\text { Novosibirskaya oblast }\end{array}$ & $\begin{array}{l}\text { wholesale market of drinking pasteurized milk (2,5 } \\
\text { percent fat) }\end{array}$ & local market & 10 \\
\hline 1 & 01.12.2009 №1 10/86-09 FAS & wholesale electricity (capacity) & local market & 10 \\
\hline 2 & $\begin{array}{l}\text { 12.10.2009 № 25/A-11-2009 FAS of } \\
\text { Kemerovskaya oblast }\end{array}$ & retail market of motor fuel & local market & 11 \\
\hline 3 & $\begin{array}{l}\text { 21.10.2009 № K 09/172 FAS of } \\
\text { Tumenskaya oblast }\end{array}$ & retail market of medicines & local market & 10 \\
\hline 4 & $\begin{array}{l}\text { 30.04.2010 № } 123 \text { FAS of } \\
\text { Kurganskaya oblast }\end{array}$ & $\begin{array}{c}\text { retail market of liquefied petroleum gas used as } \\
\text { motor fuel }\end{array}$ & local market & 11 \\
\hline 5 & 21.04.2009 №3 FAS of Altai Republic & retail market of gasoline and diesel fuel & local market & 10 \\
\hline 6 & $\begin{array}{l}\text { 18.03.2008 № } 28 \text { FAS of } \\
\text { Kaliningradskaya oblast }\end{array}$ & retail market of gasoline and diesel fuel & local market & 10 \\
\hline
\end{tabular}




\begin{tabular}{|c|c|c|c|c|}
\hline 7 & $\begin{array}{l}\text { 19.06.2009 № } 29 \text { FAS of } \\
\text { Kaliningradskaya oblast }\end{array}$ & retail market of gasoline and diesel fuel & local market & 10 \\
\hline 8 & $\begin{array}{l}\text { 23.12.2008 № 104-10K FAS of } \\
\text { Voronezhskaya oblast }\end{array}$ & retail market of gasoline and diesel fuel & local market & 10 \\
\hline 9 & $\begin{array}{l}\text { 22.04.2009 № 2-03/05-2009 FAS of } \\
\text { Penzenskaya oblast }\end{array}$ & retail market of gasoline and diesel fuel & local market & 11 \\
\hline 0 & $\begin{array}{l}\text { 02.10.2008 № K 08/65 FAS of } \\
\text { Tumenskaya oblast }\end{array}$ & retail market of gasoline and diesel fuel & local market & 11 \\
\hline 1 & $\begin{array}{l}\text { 27.01.2010 №31 FAS of } \\
\text { Sverdlovskaya oblast }\end{array}$ & retail market of gasoline & local market & 10 \\
\hline 2 & $\begin{array}{l}\text { 27.12.2010 № 54-1, 54-2, 54-3 FAS of } \\
\text { Kurganskaya oblast }\end{array}$ & retail market of gasoline & local market & 11 \\
\hline 3 & $\begin{array}{l}\text { 28.06.2010 № 17-A-10 FAS of } \\
\text { Republic of Khakassia }\end{array}$ & retail market of fuels and lubricants & local market & 10 \\
\hline 4 & $\begin{array}{l}\text { 17.12.2009 № } 276 \text { FAS of } \\
\text { Kemerovskaya oblast }\end{array}$ & retail electricity market & local market & $\begin{array}{l}\text { inclusion in } \\
\text { register* }\end{array}$ \\
\hline 5 & $\begin{array}{l}\text { 20.11.2009 № 316-09-a FAS of } \\
\text { Permskiy Kray }\end{array}$ & $\begin{array}{l}\text { rendering of communication services for cable } \\
\text { broadcasting }\end{array}$ & local market & 10 \\
\hline
\end{tabular}




\begin{tabular}{|c|c|c|c|c|}
\hline 6 & $\begin{array}{l}\text { 30.06.2008 № 151-10K FAS of } \\
\text { Voronezkaya oblast }\end{array}$ & raw milk for processing & local market & 10 \\
\hline 7 & 23.04.2007 № 1 10/11 -07FAS & potassium chloride & territory of Russia & 10 \\
\hline 8 & 23.05.2011 № 1 10/105-10 FAS & market of interconnection service & local market & 10 \\
\hline 9 & $\begin{array}{l}\text { 03.03.2009 № 01-12/38 FAS of } \\
\text { Magadanskaya oblast }\end{array}$ & lease to trade areas at the markets of food retail & local market & $\begin{array}{l}\text { inclusion in } \\
\text { register* }\end{array}$ \\
\hline 0 & $\begin{array}{l}\text { 05.06.2008 №811 FAS of } \\
\text { Rostovskaya oblast }\end{array}$ & intra-zone telephone connection & local market & 10 \\
\hline 1 & 03.11.2010 № 1 10/141-10 FAS & ethylene & local market & 10 \\
\hline 2 & $\begin{array}{c}\text { 03.06.2010 № 173 FAS of Altaiskiy } \\
\text { Kray }\end{array}$ & cable television services & local market & $\begin{array}{l}\text { inclusion in } \\
\text { register* }\end{array}$ \\
\hline 3 & $\begin{array}{l}\text { 14.12.2010 № AM3-66/2010 FAS of } \\
\text { Kaliningradskaya oblast }\end{array}$ & air traffic & local market & 10 \\
\hline
\end{tabular}

Source: compiled from the data of FAS central and regional offices decisions (posted on the websites) and decisions of courts (arbitration tribunals, courts of appeal and federal arbitration courts) of Russian Federation 
${ }^{*}$ Register $=$ Register of market participants with market share of $35 \%$ and more in relevant markets. In the Russian antitrust inclusion in the Register normally implies that market participants are recognized as dominant (though they can appeal this qualification in case of accusation. In addition, companies in the Register become automatically subject of ex-ante merger approval.

** In the Law "On protection of competition" article 10 contains prohibitions on abuse of dominance and article 11 correspondingly prohibitions on agreements and concerted practices which restrict competition. 
On the basis of Art. 5, part 3 of the Law we summarize the following groups of conditions that are required to recognize economic entities as collectively dominant:

First group: - market shares of economic entities;

Second group: - stability of the market shares over time;

- barriers to the entry of new competitors to the relevant market;

Third group: - low cross-price elasticity of demand with other commodities;

- low own-price elasticity of demand;

- wide availability of information about the price

- wide availability of information about conditions of selling or purchasing the commodity.

The number of times each of these factors is cited in our cases is presented in chart 1.

\section{Chart 1. Number of Cases that Include Certain Indicators of Collective Dominance}

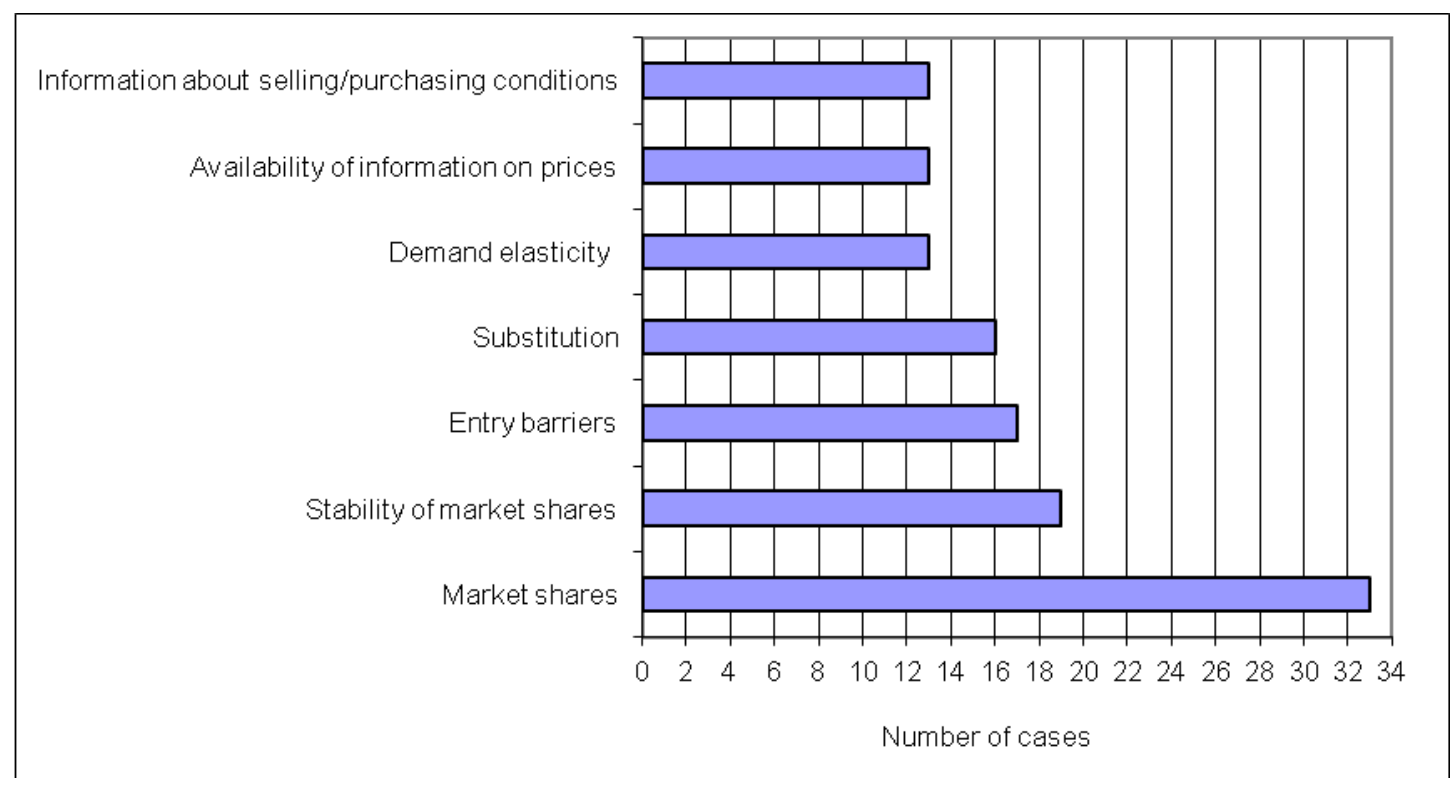

As may be seen from chart 1, it appears from the information made available that cases do not always contain all the elements necessary to prove collective dominance listed in the law. FAS has apparently devoted most of its attention to the 
first group of conditions, market shares -- these were examined in all 33 cases. In 14 cases of 33 market shares were the only evidence reported in favor of collective dominant position of economic entities.

According to the Guidelines of market competition analysis elaborated by FAS, the notion of "stability of market shares" means that during a long period (not less than a year, except in cases where the relevant commodity market has existed for less than a year, in which case the period considered is the full time of the market's existence) the relative sizes of such economic entities' shares are stable or subjected to insignificant changes. In cases where stability of shares was analyzed, FAS usually considered nearly 2-year periods of analysis. However, in several cases it was impossible to determine the period of analysis because the text of the decision contained only the following phrase: "the relative sizes of economic entities' shares were stable during a long period". There is one more area of uncertainty in this legal construction: What level of variation in shares is considered "insignificant"? In decision № 1 10/141-10²8 (against the Salavatnefteorgsintez company) FAS analyzed stability of shares during 19 months, and increase/decrease of share of $5.5 \%$ was regarded as insignificant. The analysis of cases hasn't answered for this question completely because mostly the decisions contain reference to insignificant changes or invariability of shares without indication the size of changes.

The stability in the relative sizes of economic entities' shares and impeded access to the commodity market by entry barriers for new competitors (second group) were analyzed by FAS or the courts in 19 and 17 cases, respectively. Only 15 of 33 reported cases contained evidence relating to both first and second groups. The third group of conditions was the least frequent: there are 19 cases that contained at least one of the conditions listed in the third group, but only 9 of these contained all conditions for this group.

\footnotetext{
${ }^{28}$ http://www.fas.gov.ru/solutions/solutions_31505.html
} 
Overall we found that evidence relating to all three groups of conditions that are required to classify economic entities as collectively dominant was reported in only 9 cases. This would suggest that economic entities can dispute whether the collective dominance position has been proved by referring to the second and third groups of conditions, but in practice they usually limit themselves to disputing the first group.

We have found information that the decisions of 26 of the 31 cases were being disputed in the courts. The distribution of the grounds on which FAS decisions were appealed is presented at Chart 2.

The definition of the product market is the element of analysis that is disputed in the courts most frequently in comparison with other elements. In our sample this occurred in 20 of 31 cases. Among them were 7 cases where the method of defining the product market boundaries was disputed. The procedure of establishing the product boundaries normally requires using a method based on the information received from customers of the product or on the result of survey sample of customers. ${ }^{29}$ In case № A21- 4754/2009 ${ }^{30}$ (declarant: Lukoil-Severo-Zapadnefteproduct, defendant: FAS, Kaliningrad regional office) the declarant complained that FAS used a method based only on information received from sellers of the product and did not substantiate why it could not use the standard method. The court supported the position of the declarant.

In 17 of 31 cases the economic entities disputed the definition of the geographical boundaries of the market. For example, in case № A27-5320/2010 ${ }^{31}$, the accused firm argued that two cities had been wrongly included in the geographic

${ }^{29}$ Order of FAS of Russia № 220 “About approval of guidelines to analyze competition at the product market".

${ }^{30}$ http://ras.arbitr.ru/data/pdf/b6c02f1b-3f86-4732-8fcf-e711364b0fa9/\%D0\%9021-47542009 20100310.pdf.

${ }^{31}$ http://kad.arbitr.ru/data/pdf/7dd8056c-4014-436c-acf1-b54468ac0769/A27-5320201020100709 Reshenija+i+postanovlenija.pdf. 
boundaries of the market. FAS admitted this mistake but convinced the court that this circumstance did not affect the validity of its conclusion about the dominant position of the applicant in the local product market. Therefore, the decision about the position of collective dominance remained in force.

\section{Chart 2. Number of Cases in which Certain Components of Analysis were Disputed}

\section{at Courts}

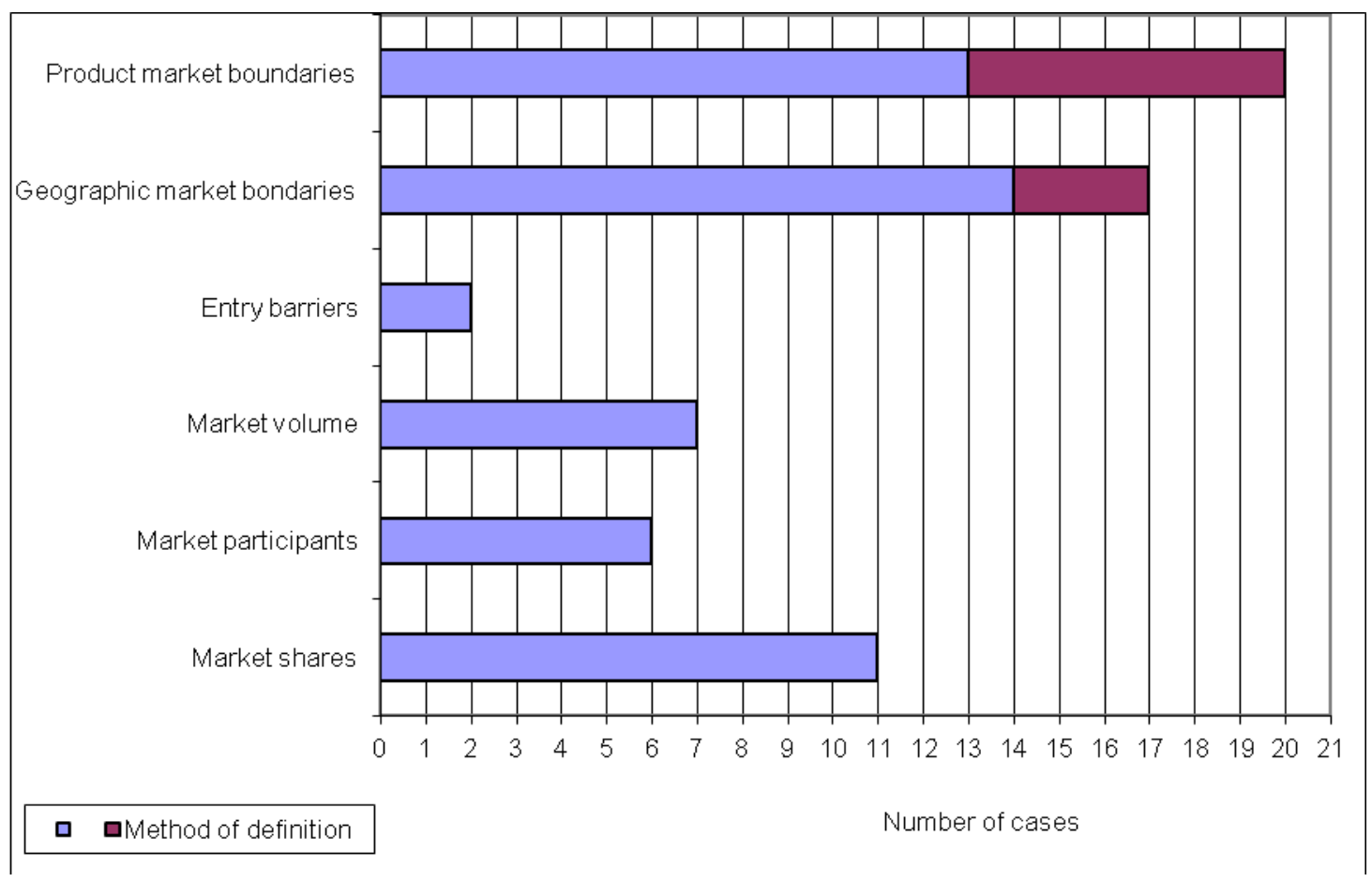

The volume of the product market, the market participants, and their shares were also frequently the subject of appeals. In contrast, entry barriers for new competitors were the grounds for appeal in only 2 cases. In one of these cases the economic entities showed that during the period of analysis, two new competitors entered the market and argued that this provided evidence that entry barriers are surmountable.

This analysis confirms that in cases of collective dominance, structural analysis prevails, and the characteristics of market structure are used both by FAS and economic 
entities in making their cases. The most important elements of analysis are the definitions of product and geographic markets. The least used elements (and indications of collective dominance) are entry barriers, elasticity of demand, and the availability of information about the price and conditions of selling or purchasing.

The majority of the cases we have collected regarding collective dominance concern the abuse of a dominant position. In our sample we have cases with the following alleged forms of abuse:

- establishment and maintaining of monopolistically high or monopolistically low price for a commodity, corresponding to excessively high and predatory price in international practice (11 cases);

- withdrawal of a commodity from circulation, if the result of such withdrawal is increase of price of the commodity (3 cases);

- imposing on a counterparty contractual terms which are unprofitable for the latter or not connected with the subject of agreement (exploitation of counterparty) (1 case);

- economically or technologically unjustified reduction or cutting off the production of a commodity (1 case);

- economically or technologically unjustified refusal to conclude a contract with individual purchasers (customers) (as a form of discrimination) (2 cases);

- economically, technologically or in any other way unjustified establishment of different prices (tariffs) for one and the same commodity, as another type of discrimination (7 cases);

- creation of discriminatory conditions broadly (10 cases);

- violation of the procedure of pricing established by sector-specific statutory legal acts ( 1 case).

In a significant number of cases the form of abuse is excessive price. As noted above, excessive price is defined in article 6 of the competition law as price exceeding the price of the comparable competitive market or (if there are no comparable competitive markets) the sum of costs and profits needed for production and sale. 
According to the Law the comparable commodity market is a market comparable by the structure of customers or sellers of the product, by the conditions of circulation and access at product market, by the government control including taxation and customs/tariff regulation. As noted, the second part of the definition of excessive price, relying on the analysis of costs and profits, is used more often in Russian antimonopoly cases because of very strict criteria to consider a market as comparable. However, as also noted, the definition of costs and profit needed for production and sale is absent at the Law. The Law also does not determine the allowable profit margin of firms or rate of return of capital.

In the case of Aeroflot the FAS analyzed the increase of air fares on the MoscowKaliningrad and Kaliningrad-Moscow routes. FAS considered cost data and concluded that the increase in prices of airline tickets did not correspond to the cost increases. So the prices were examined as monopolistically high. More detailed analysis of prices was not presented in the text of the decision. However, this decision was overruled by the Court. One of the key arguments in favor of Aeroflot's position was its demonstration that during the time period in question, it lost money on this route. ${ }^{32}$

To analyze the price level at the retail market of gasoline and diesel fuel, FAS used data on wholesale prices, price markups, distribution costs and retail prices. In the case of LUKOIL-Severo-Zapadnefteprodukt, ${ }^{33}$ FAS showed that retail prices had fallen significantly less than wholesale prices.

The case of Krasnoyarsknefteproduct ${ }^{34}$ stands out from the two previously considered cases because of the great detail of analysis reported. FAS analyzed the retail market for fuels and lubricants at the local level (the village of Kopyevo in

${ }^{32}$ http://kad.arbitr.ru/data/pdf/ed4e2832-ca4e-4aa0-952a-33433dcabc34/A21-2026-

\section{$\underline{201120110629 \text { Reshenija+i+postanovlenija.pdf }}$}

${ }^{33}$ http://kaliningrad.fas.gov.ru/news.php?id=214

${ }^{3434}$ the case №23 (28.06.2010 № 17-A-10 FAS of Republic of Khakassia) 
Krasnoyarsk oblast) and found that two firms were in a position of collective dominance. In addition to analysis of wholesale prices, price markups, distribution costs, and retail prices in the village, FAS examined retail prices in comparable markets. In the end, FAS concluded that there was no unjustified increase of profitability, and thus no violation of the law. ${ }^{35}$

In those cases from our sample that come from the courts, the subjects of consideration are not only cases where companies are accused of abuse of dominant position: we have 3 cases where FAS made a decision to include economic entities in the official register of firms in a dominant position, and the entities disputed this decision in the courts. Companies turn to courts because inclusion in the register increases the risk of antitrust prosecution (Article 10 can be applied to companies) and may also increase administrative costs (for example, mergers involving firms on the register must receive ex ante FAS approval).

We also found that in 5 of the 33 cases, the finding of collective dominance was used as evidence supportive of a finding of concerted practices (Article 8) or the anticompetitive nature of agreements (Article 11 ).

In the decision № A49-4101/2009 36 of the Eleventh Arbitration Court of Appeals, the court noted that the concentrated structure of the market enabled the companies to trace and assess the market behavior (price policy) of their competitors. The court noted that the information on the prices of petroleum products is publicly available, as it is displayed at the gas station. Moreover, the possibility of the parallel, "cooperative" behavior could be ensured without explicit agreement, written or otherwise.

In the decision № 25/A-11-2009, 37 Gazprom Neft-Kuzbass, Barrel and "Center" Company were recognized as collectively dominant in the retail market of motor fuel.

\footnotetext{
${ }^{35}$ http://hakasia.fas.gov.ru/news.php?id=1066

${ }^{36}$ http://kad.arbitr.ru/data/pdf/e77e500f-da91-4629-b626-6e165875219c/A49-4101-
} $\underline{200920100830 \text { Postanovlenie+apelljacii.pdf. }}$

${ }^{37}$ http://kemerovo.fas.gov.ru/page.php?id=321. 
Such a position in the market was considered as an argument in favor of the conclusion that concerted practices took place. For example, Gazprom Neft-Kuzbass has more gas stations at Kemerovo than other economic entities. The court concluded that if Gazprom Neft-Kuzbass decides to increase prices on oil products, it faces only a small risk of loss of customers as it has every reason to believe that this change will be reflected in the prices of Barrel and Company "Center". In fact the market exhibited systematic, uniform and relatively synchronous changes of prices.

So we can see that the definition of collective dominance is applied, as well as disputed, in a number of different ways. Firms may challenge a finding of collective dominance in order to fight a charge of abuse or simply to win removal from the register of dominant firms. In addition, FAS and the courts have considered a finding of collective dominance as supportive of findings of anticompetitive agreements, tacit or explicit.

\section{COLLECTIVE DOMINANCE IN THE MARKETS FOR OIL PRODUCTS}

The concept of collective dominance was applied in the largest and most visible groups of cases against Russian oil companies - Lukoil, TNK-BP, Rosneft, and Gazprom Neft. Overall there were several hundred cases of all kinds initiated by the Central Office and regional subdivisions of FAS against the oil companies and their subsidiaries in 2008-2011. The most important of these were two sets of cases alleging the abuse of collective dominance, the first begun in autumn 2008 and the second in summer 2009. Both resulted in final decisions by the Supreme Arbitration Court of Russian Federation - in May 2010 (FAS against TNK-BP) and in February 2011 (FAS against Gazprom Neft). The forms of abuse of dominance in these two cases differed. In the first cases the companies were accused of excessive ("monopolistically high") prices and discrimination among buyers in wholesale market of oil products, while in the second, of "unjustified withdrawal of a commodity from the market" and discrimination. However, the standards of proving the collective dominance in the two decisions of RF Supreme Arbitration Court were very close. 
Analysis of these cases is interesting for several reasons. First of all, these are cases against some of the largest companies in Russia. The sum of sales proceeds of these companies equals nearly $15 \%$ of the GDP of Russia. Second, these markets are very important from the social point of view. The Prime Minister has repeatedly spoken about the need to control price increases in retail fuel markets. Third, two of these cases were considered by the Supreme Arbitration Court, so these decisions must be employed when courts consider similar cases. Finally, these decisions of FAS contain more detailed analysis than many other published decisions.

During September-October 2008 FAS identified these four oil companies as collectively dominant. ${ }^{38}$ The product boundaries of market were defined as the wholesale markets for gasoline, diesel fuel, heating fuel oil, and aircraft kerosene. According to FAS the geographic boundaries of these markets cover the territory of Russia. Such identification of geographical boundaries became a subject of disputes in the courts because, according to the competition law, the geographic boundaries of the market should be defined based on the possibilities of customers to buy the product and on the economic feasibility of switching to another seller in the geographic market.

The Supreme Arbitration Court made a final decision on this dispute. According to its decisions № $16678 / 09^{39}$ (FAS against TNK-BP) and № $12221 / 2010^{40}$ (FAS against Gazprom Neft) the geographic boundaries of the market is the territory of the Russian Federation, as the sales of petroleum products was carried out in all regions of the

${ }^{38}$ Decision on Gazprom Neft case: http://www.fas.gov.ru/solutions/solutions 29738.html Decision on LUKOIL case: http://www.fas.gov.ru/solutions/solutions 29737.html Decision on Rosneft case: http://www.fas.gov.ru/solutions/solutions 29743.html Decision on TNK-BP case:

${ }^{39}$ http://ras.arbitr.ru/data/pdf/fedb29ee-f511-4da8-be11-16278cf7c27f/\%D0\%9070-9090$2015 \quad 20100525 . p d f$

${ }^{40}$ http://kad.arbitr.ru/?id=5f73f3d9-a5ad-4fd6-a93d-b32a591bfe66 
Russian Federation by collectively dominant vertically integrated entities. The main reasoning of such broad definition of geographical market boundaries was based on the nationwide allocation of oil-processing enterprises of the companies. The ability of buyers to substitute the delivery from sellers in different regions of this national geographic market was not addressed by the court. These market boundaries were used to calculate market shares of the firms. The individual and collective market shares of the four companies exceeded the threshold set by the law regarding collective dominance, and the size of shares was considered by the court as a main indicator of collective dominance.

Regarding entry barriers, the Supreme Arbitration Court mentioned only vertical integration in oil production, processing, wholesale and retail trade. According to its decision, vertical integration itself discourages entry into all the markets along the value chain.

Regarding the own-elasticities of demand facing the companies, FAS showed that in all four markets the rate of increase in prices exceeded the rate of decrease in quantity demanded. Other factors that could influence the demand (change in incomes, seasonal variations) were not considered. Consequently the elasticity calculations potentially missed the "other things being equal" condition. At its decision the FAS considered such lack of correspondence between price and quantity changes as evidence of collective dominance.

In the first wave of cases the companies were charged with various types of violations, but all of them were accused of setting monopolistically high prices. All four decisions contain only analysis of costs and profits as the courts ruled that there was no way to find comparable commodity markets. Such an approach to the analysis of monopolistically high prices was supported by the Supreme Arbitration Court.

This part of decision of the FAS concluded that the increases in the prices of the products charged by the companies were greater than the increases in their costs, and were also greater than the increase in the wholesale price index for the economy. (It is unclear how important this second conclusion was for FAS.) 
All of these conclusions contain analyses of the prices, costs, and profits "needed for production and sale". However, as mentioned above, the law does not provide specifics on what price mark-ups or profit rates might be "needed" in a market, nor what determines whether increases in those rates are permissible. (For example, could the companies seek to show that last period's profits were below what is "needed", so that price increases greater than cost increases this period are "needed"?)

As the prices of oil in Russian markets are influenced by prices on world markets, FAS analyzed the dynamics of these markets for the period October 2007 - September 2008. FAS found that when wholesale oil products prices increased on the external market, domestic retail prices increased at the same or higher rate, and the lag was minimal. On the other hand, when wholesale oil prices fell on the external market, domestic retail prices fell at lower rate or did not fall at all - and the lag of falling retail prices after falling wholesale prices was greater than when prices were increasing.

In the second case the accusation of "unjustified withdrawal of a commodity from the market" replaced the accusation of "excessive price". The increase of export volumes were regarded as a cause for the reduction in quantity and the increase of prices of oil products in domestic retail markets in the early 2009. This suggests a role for the government corresponding to the "price regulator" role implied by the judging of reasonable margins of cost over price: to avoid the accusation of "unjustified withdrawal of commodity from the market", must a dominant firm seek a ruling from FAS or the government as to its permitted level of exports?

In both cases - the decision on Gazprom Neft case as well as on TNK-BP - the principal form of discrimination found to violate the law was the charging of higher prices to independent wholesale customers as compared to the prices charged to company subsidiaries. In addition, there was some emphasis placed on the refusal to supply independent wholesale customers during periods of supply shortage.

\section{CONCLUSIONS}

Russia is a country with its own unique economic and political problems and challenges. Among these is its legacy of state economic control and monopoly and 
"giantism" of economic enterprises. A great deal of debate has already taken place concerning the best ways to reform and restructure markets in order to create and encourage the forces of competition going forward. ${ }^{41}$

One recommended strategy has been an antimonopoly policy more aggressive than that found in countries with more market-friendly histories, like the US and countries of the EU. ${ }^{42}$ A country that inherits a legacy of highly concentrated industries may choose to place more emphasis in its competition law enforcement strategy on addressing the abuse of dominant positions than other countries. Within the area of abuse of a dominant position, it may place more emphasis on exploitative abuses than other countries, since an economy dominated by concentrated industries may find fewer (and/or more distant future) benefits from waiting for the forces of entry and competition to protect consumers. Among the tools chosen for this emphasis on

\footnotetext{
${ }^{41}$ See, for example, Anders Åslund, How Russia Became a Market Economy, Brookings, 1995; James
} Leitzel, Russian Economic Reform, Routledge, 1995; Clifford Gaddy, The Price of the Past: Russia's Struggle with the Legacy of a Militarized Economy, Brookings, 1996; Marshall Goldman, Lost Opportunity: What Has Made Economic Reform in Russia So Difficult?, Norton, 1996; and Erik Berglöf, Andrei Kunov, Julia Shvets, and Ksenia Yudaeva, The New Political Economy of Russia, MIT Press, 2003.

${ }^{42}$ See, for example, Vladimir Capelik and Ben Slay, Antimonopoly Policy and Monopoly Regulation in Russia, in Ben Slay, ed., De-monopolization and Competition Policy in Post-Communist Economies, Westview, 1996; Russell Pittman, Abuse-of-Dominance Provisions of Central and Eastern European Competition Laws: Have Fears of Over-Enforcement Been Borne Out?, World Competition 27 (2004), 245258; and Andrei Shastitko, Don't Throw Out the Baby with the Bathwater: On the Relationship Between Antitrust Policy and Economic Development, Problems of Economic Transition 47 (2004), 27-36. 
detecting and attacking exploitative abuses might be tools for addressing tacit collusion among collectively dominant firms in a market. All of this seems to characterize Russia today.

Of course, this is not the only strategy available for attacking the problems associated with a heritage of concentrated markets; nor is it the only strategy being utilized by the government of the RF. ${ }^{43}$ Other policies that can be and are being used include the reduction of barriers to international trade, the improvement of transport infrastructure, the investigation and prosecution of protectionist actions by local and regional governments (under Articles 15 and 16 of the competition law), the encouragement of innovation, the introduction of competition into "natural monopoly" sectors, ${ }^{44}$ and, indeed, strict enforcement against anticompetitive mergers and agreements.

In this paper we have examined the enforcement and litigation results of the use of a new tool for attacking tacit collusion: the bringing of cases against the abuse of a position of collective dominance in a market. Experience with this and similar tools in other jurisdictions suggested that it would be difficult for antimonopoly authorities to

\footnotetext{
${ }^{43}$ See, for example, Svetlana Avdasheva and Andrei Shastitko, Industrial Policy and Competition
} Policy: Problems of Interaction and Lessons for Russia, Problems of Economic Transition 47 (2004), 48-65.

${ }^{44}$ See Geido Friebel, Sergei Guriev, Russell Pittman, Elizaveta Shevyakhova, and Anna Tomová, Railroad Restructuring in Russia and Central and Eastern Europe: One Solution for All Problems?, Transport Reviews 27 (2007), 251-271, and Pittman, Restructuring the Russian electricity sector: Recreating California?, Energy Policy 35 (2007), 1872-1883. 
utilize it without interfering in some of the most sensitive and important of the decisions made by firms: what prices to set and to which customers to sell. Based on the cases brought and disputed so far, the lessons of the experience seem accurate. Most importantly, as experience in other jurisdictions confirms, it is very difficult for a competition agency or judicial tribunal to judge what price increases should be permitted to firms with market power.

This is not to suggest that the adoption of this new legal tool was or was not a good idea. It is to suggest that this tool has problems like any other, and that these problems should be kept in mind as the country goes forward in antimonopoly enforcement. We hope that our analysis will serve to contribute to the learning from experience that will continue to strengthen Russian antimonopoly enforcement in the years to come. 